Thorax (1975), 30, 563.

\title{
Effect of lung resection for bronchial carcinoma on pulmonary function in patients with and without chronic obstructive bronchitis
}

\author{
J. S. LEG G E a n $\mathrm{d}$. N . V. P A L M E R \\ Department of Medicine, University of Aberdeen
}

\begin{abstract}
Legge, J. S. and Palmer, K. N. V. (1975). Thorax, 30, 563-565. Effect of lung resection for bronchial carcinoma on pulmonary function in patients with and without chronic obstructive bronchitis. Pulmonary function was measured before and after lung resection (pneumonectomy or lobectomy) in 58 patients with bronchial carcinoma, 33 of whom also had chronic obstructive bronchitis. Lung resection was well tolerated and caused no greater impairment of lung function postoperatively in the bronchitics than in those without bronchitis.
\end{abstract}

In a previous report of 330 patients with bronchial carcinoma, $62 \%$ had impaired pulmonary function due to coincident chronic obstructive bronchitis (Legge and Palmer, 1973), this diagnosis being based on criteria from a report to the Medical Research Council (1965), namely dyspnoea on exertion, chronic or recurrent mucopurulent sputum, and persistent widespread narrowing of the intrapulmonary airways at least on expiration as shown by spirometry. Lung resection in such patients may result in an unacceptable degree of dyspnoea or ventilatory failure. We have now investigated the results of lung resection in a group of 58 patients with bronchial carcinoma, 33 of whom $(57 \%)$ had chronic obstructive bronchitis according to the MRC criteria with a forced expiratory volume in one second as a percentage of the forced vital capacity $\left(\mathrm{FEV}_{1} \%\right)$ of less than 70 but who were considered fit for operation on other clinical and pulmonary function criteria (Legge and Palmer, 1973).

\section{PATIENTS AND METHODS}

Fifty-eight patients with histologically proven bronchial carcinoma were divided into groups according to whether the $\mathrm{FEV}_{1} \%$ was greater or less than 70 . Group I, in which the $\mathrm{FEV}_{1} \%$ was greater than 70 , comprised 25 patients, 20 men and 5 women, mean age 61.5 (range 42-77) years, mean height 1.68 (range 1.53-1.80) metres, and mean weight 65.9 (range $49-83$ ) $\mathrm{kg}$. In group
II, the $\mathrm{FEV}_{1}$ was less than 70 . Here there were 33 patients, 31 men and 2 women, mean age 60.5 (range 37-73) years, mean height 1.69 (1.52-1.88) metres, and mean weight $70 \cdot 0(54-102) \mathrm{kg}$. Dynamic and static lung volumes, transfer factor, and arterial blood gas tensions were measured in all patients before and between three and six months after lung resection.

To determine the dynamic lung volumes, the forced vital capacity (FVC), forced expiratory volume in one second $\left(F E V_{1}\right)$, and the $F_{E V}$ as a percentage of the FVC $\left(\mathrm{FEV}_{1} \%\right)$ were calculated in litres from the best of three forced expiratory spirograms.

To determine the lung volumes, the functional residual capacity (FRC) was measured in duplicate by the closed-circuit multiple breath helium dilution method, and after measuring the inspiratory capacity and expiratory reserve volume, the total lung capacity (TLC), residual volume (RV), and RV $/$ TLC $\%$ were calculated in litres (ATPS).

Single breath carbon monoxide transfer factor (TF) was measured in duplicate by the method of Ogilvie et al. (1957).

Arterial blood samples were obtained with the patient breathing air and the arterial oxygen $\left(\mathrm{PaO}_{2}\right)$ and carbon dioxide $\left(\mathrm{PaCO}_{2}\right)$ tensions were measured in duplicate using electrodes (Radiometer, Copenhagen).

The mean values for $\mathrm{FEV}_{1}$ and FVC, lung volumes, and TF are expressed as the per cent of predicted normal values from the tables of Cotes 
(1968) to allow for variations in age, sex, and height.

Of the 25 patients in group I, 12 had a lobectomy and 13 had a pneumonectomy. Of the 33 patients in group II, 20 had a pneumonectomy and 13 had a lobectomy.

\section{RESULTS}

A comparison of preoperative pulmonary function is shown in Table $\mathrm{I}$; per cent predicted $\mathrm{FEV}_{1}$, $\mathrm{FEV}_{1} \%$, and $\mathrm{TF}$ were all significantly less in group II while in these subjects per cent predicted RV was significantly more.

Table II shows a comparison of the changes in pulmonary function measurements between the groups after pneumonectomy. In both, the dynamic and static lung volumes fell from between $20-30 \%$ but there was no significant difference in this fall between the groups. The $\mathrm{FEV}_{1} \%$ rose significantly $(\mathrm{P}<0.05)$ in the bronchitic group. The $\mathrm{PaO}_{2}$ rose by about $0.67 \mathrm{kPa}$ in both groups and this rise, compared with the preoperative value, is significant $(\mathrm{P}<0 \cdot 05)$.

Table III shows a comparison of the effects of lobectomy on pulmonary function in the groups. Again there is a fall, though a smaller one, in the region of $15 \%$ in the dynamic and static lung volumes, and a fall in TF. The changes were not

T A B L E I

PREOPERATIVE PULMONARY FUNCTION IN GROUPS I AND II

\begin{tabular}{|c|c|c|c|}
\hline & $\begin{array}{c}\text { Group I } \\
\left(\mathrm{FEV}_{1} \%>70\right)\end{array}$ & $\begin{array}{c}\text { Group II } \\
\left(\mathrm{FEV}_{1} \%<70\right)\end{array}$ & $\mathbf{P}$ \\
\hline $\begin{array}{l}\text { FEV } \% \text { of predicted } \\
\text { FVC\% of predicted } \\
\text { FEV } \% \% \\
\text { TLC\% of predicted } \\
\text { FRC \% of predicted } \\
\text { RV \% of predicted } \\
\text { RV/TLC } / \text { LC } \\
\text { TF\% of predicted } \\
\mathrm{PaO}_{2}(\mathrm{kPa}) \\
\mathrm{PaCO}_{2}(\mathrm{kPa})\end{array}$ & $\begin{array}{r}84 \cdot 5 \\
86 \cdot 8 \\
75 \cdot 5 \\
95 \cdot 8 \\
123 \cdot 5 \\
116 \cdot 0 \\
43 \cdot 3 \\
78 \cdot 6 \\
10 \cdot 1 \\
5 \cdot 3\end{array}$ & $\begin{array}{r}73 \cdot 0 \\
94 \cdot 1 \\
58 \cdot 2 \\
105 \cdot 0 \\
138 \cdot 8 \\
138 \cdot 9 \\
45 \cdot 0 \\
64 \cdot 1 \\
10 \cdot 4 \\
5 \cdot 4\end{array}$ & $\begin{array}{l}<0.05 \\
\text { NS } \\
<0.01 \\
\text { NS } \\
\text { NS } \\
<0.05 \\
\text { NS } \\
<0.05 \\
\text { NS } \\
\text { NS }\end{array}$ \\
\hline
\end{tabular}

T A B L E I I

MEAN PERCENTAGE CHANGE IN PULMONARY FUNCTION AFTER PNEUMONECTOMY

\begin{tabular}{|c|c|c|c|}
\hline & $\begin{array}{c}\text { Group I } \\
\left(\text { FEV }_{1} \%>70\right)\end{array}$ & $\begin{array}{c}\text { Group II } \\
\left(\text { FEV }_{1} \%<70\right)\end{array}$ & $\mathbf{P}$ \\
\hline 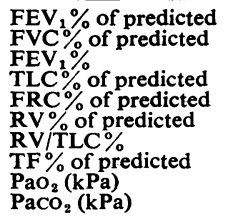 & $\begin{array}{l}-25 \cdot 8 \\
-24 \cdot 6 \\
-1 \cdot 1 \\
-26 \cdot 1 \\
-22 \cdot 8 \\
-16 \cdot 7 \\
+1 \cdot 1 \\
+2 \cdot 2 \\
+0 \cdot 84 \\
+0.01\end{array}$ & $\begin{array}{l}-28 \cdot 6 \\
-37.6 \\
+6.8 \\
-30.3 \\
-31 \cdot 5 \\
-26.5 \\
+2.5 \\
+.8 .4 \\
+0.65 \\
-0.05\end{array}$ & $\begin{array}{l}\text { NS } \\
\text { NS } \\
<0 \cdot 05 \\
\text { NS } \\
\text { NS } \\
\text { NS } \\
\text { NS } \\
\text { NS } \\
\text { NS } \\
\text { NS }\end{array}$ \\
\hline
\end{tabular}

T A B L E I I I

MEAN PERCENTAGE CHANGE IN PULMONARY FUNCTION AFTER LOBECTOMY

\begin{tabular}{|c|c|c|c|}
\hline & $\begin{array}{c}\text { Group I } \\
\left(\mathrm{FEV}_{1} \%>70\right)\end{array}$ & $\begin{array}{c}\text { Group II } \\
\left(\text { FEV }_{1} \%<70\right)\end{array}$ & $\mathbf{P}$ \\
\hline $\begin{array}{l}\text { FEV } \% \text { of predicted } \\
\text { FVC\% of predicted } \\
\text { FEV } \% \text { o } \\
\text { TLC\% of predicted } \\
\text { FRC\% of predicted } \\
\text { RV\% of predicted } \\
\text { RV/TLC \% } \\
\text { TF } \% \text { of predicted } \\
\mathrm{PaO}_{2}(\mathrm{kPa}) \\
\mathrm{PaCO}_{2}(\mathrm{kPa})\end{array}$ & $\begin{array}{l}-18.8 \\
-15 \cdot 7 \\
-1.4 \\
-15 \cdot 0 \\
-12 \cdot 7 \\
-10 \cdot 3 \\
+2 \cdot 6 \\
-11 \cdot 0 \\
-0.39 \\
+0.12\end{array}$ & $\begin{array}{l}-11 \cdot 2 \\
-16.8 \\
+\quad 3.5 \\
-15.1 \\
-11 \cdot 2 \\
-15.8 \\
+0.2 \\
-12.3 \\
-0.15 \\
-0.16\end{array}$ & $\begin{array}{l}\text { NS } \\
\text { NS } \\
\text { NS } \\
\text { NS } \\
\text { NS } \\
\text { NS } \\
\text { NS } \\
\text { NS } \\
\text { NS } \\
\text { NS }\end{array}$ \\
\hline
\end{tabular}

significantly different between the two groups, क्ष and the blood gas tensions were not altered fromo the preoperative values.

\section{DISCUSSION}

As a result of lung resection, the dynamic ando static lung volumes fell more after pneumonec $\vec{c}$ tomy than lobectomy. This reflects the removal of lung tissue and has been described before (Cournand and Berry, 1942; Curtis et al., 1959; Bie, Erikson, and Refsum, 1960). A reduced $\mathrm{FEV}_{1} \%$ \% may be found in patients with bronchial car-o cinoma where there is local obstruction to theo bronchus by the tumour, in addition to generalized? airway obstruction due to chronic obstructive $\overrightarrow{0}$ bronchitis (Simonsson and Malmberg, 1964). The 3 significant postoperative rise in the $\mathrm{FEV}_{1} \%$ and the larger postoperative fall in $\mathrm{RV}$ in group $\mathrm{I}$. patients after pneumonectomy might reflect an improvement in airway obstruction due to re-을 moval of the tumour rather than improvement inx bronchitis.

The mean RV/TLC\% was unaltered by either procedure, indicating that hyperinflation of the remaining lung did not develop during the first postoperative year. Similar results were found bys Friend (1954) and Ogilvie et al. (1963) at 10 years?

TF fell in the group II patients after pneumon ectomy but this difference did not vary signifi N cantly from a slight rise in the group I patients Wide variations in the postoperative TF were noted. This has been observed also by Curtis et al (1967).

After pneumonectomy, there was a significane rise in $\mathrm{PaO}_{2}$ in both groups but no change in $\mathrm{PaCO}_{2} \stackrel{\$}{\mathrm{D}}$ This improvement in $\mathrm{PaO}_{2}$ may have resulted from ${ }^{+}$ the removal of arteriovenous shunts commonly found in patients with bronchial carcinoma (Cud $\stackrel{\circ}{\mathbb{D}}$

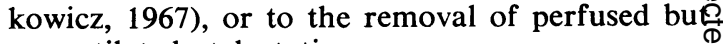
unventilated atelectatic areas.

We have previously shown that, in patients with chronic airways obstruction, the following tests of 
pulmonary function were most valuable in predicting the risk of postoperative ventilatory failure: $\mathrm{FEV}_{1}, \mathrm{FEV}_{1} \%, \mathrm{RV}, \mathrm{RV} / \mathrm{TLC} \%, \mathrm{PaCo}_{2}$, respiratory rate, and $\mathrm{VD} / \mathrm{VT}$ on exercise. On the other hand, the FVC, TLC, FRC, TF, $\mathrm{PaO}_{2}$, minute ventilation, and the heart rate on exercise were not found helpful in recognizing this high risk group (Legge and Palmer, 1973). In the present study, the preoperative values for $\mathrm{FEV}_{1} \%$ and TF were significantly lower and the RV significantly higher in group II than in group I patients, but there was no significant difference in $\mathrm{RV} / \mathrm{TLC} \%$ and $\mathrm{PaCO}_{2}$ between the two groups.

Our thanks are due to Mr. F. J. Sambrook Gowar and Mr. P. L. Brunnen for permission to study their patients, and to Fiona Fiddes and Keith Minty for technical assistance. During this work Dr. Legge held a Medical Research Council Junior Fellowship. We gratefully acknowledge the support given by the Medical Research Council.

\section{REFERENCES}

Bie, K., Erikson, H., and Refsum, H. E. (1960). Surgical and functional results after pneumonectomy in patients with carcinoma of the lung. Acta Chirurgica Scandinavica, 119, 289.

Cotes, J. E. (1968). Lung Function, 2nd ed. Blackwell, Oxford.

Cournand, A. and Berry, F. B. (1942). The effect of pneumonectomy upon cardiopulmonary function in adult patients. Annals of Surgery, 116, 532.

Cudkowicz, L. (1967). Cardiorespiratory studies in patients with lung tumors. Diseases of the Chest, 51, 427.
Curtis, J. K., Bauer, H., Rasmussen, H. K., and Mendenhall, J. T. (1959). Studies of pulmonary function before and after pulmonary surgery in 450 tuberculous patients. I. Vital capacity and maximum breathing capacity. Journal of Thoracic Surgery, 37, 598.

—, Rasmussen, H. K., Wright, F., Cree, E. M., and Mendenhall, J. T. (1967). Studies of pulmonary function before and after pulmonary surgery. III. Breathholding carbon monoxide diffusion of each lung before and after pneumonectomy. Journal of Thoracic and Cardiovascular surgery, 45, 166.

Friend, J. (1954). Respiratory insufficiency after pneumonectomy. Lancet, 2, 260.

Legge, J. S. and Palmer, K. N. V. (1973). Pulmonary function in bronchial carcinoma. Thorax, 28, 588.

Medical Research Council (1965). Definition and classification of chronic bronchitis for clinical and epidemiological purposes. Lancet, 1, 775.

Ogilvie, C. M., Forster, R. E., Blakemore, W. S., and Morton, J. W. (1957). A standardised breathholding technique for the clinical measurement of the diffusing capacity of the lung for carbon monoxide. Journal of Clinical Investigation, 36, 1 .

- Harris, L. H., Meecham, J., and Ryder, G. (1963). Ten years after pneumonectomy for carcinoma. British Medical Journal, 1, 1111.

Simonsson, B. G. and Malmberg, R. (1964). Differentiation between localized and generalized airway obstruction. Thorax, 19, 416.

Requests for reprints to: Dr. K. N. V. Palmer, Department of Medicine, Foresterhill, Aberdeen, AB9 2ZD. 